\title{
Covid-19 and Forest Communities: Alignment and Challenges on Case Studies in Forest Community, Pemalang, Indonesia
}

Robert Siburian ${ }^{1,}$ *, Dicky Rachmawan ${ }^{1}$, and Fanny Henry Tondo ${ }^{1}$ RECEIVED 2020-08-10
ACCEPTED 2022-01-17

COPYRIGHT @ 2022 by Forest and Society. This work is licensed under a Creative Commons Attribution 4.0 International License

\begin{abstract}
A pandemic, last seen a century ago, has reappeared in 2019 under the name of Covid-19. Poor forest communities are also especially affected by this pandemic. The qualitative method through literature and case study is used to explain the connection between the emergence of COVID-19, forest destruction, and its impact on the lives of people in forests in Indonesia. Two cases are going to be models of forest communities in Pemalang, namely LMDH Rawa Sakti and KTH GGL. The program was established by the Ministry of Environment and Forest (MoEF) to create a supportive atmosphere for forest communities' survival to overcome the Covid-19 crisis. We use the new institutionalism concept introduced by Victor Nee (2003) to understand how the coupling within the affirmation concept was developed at micro-level in Indonesia. The result shows that there are unique and complex situations, especially between the social groups, the members (as the individual), and other actors that are not examined by new institutionalism, which are important to reach collective action or influence the situation. In the KTH GGL context, Juragan (as the other actor) determines the commodity although many members want to plant ginger that aligns with the Ministry of Environment and Forest's suggestion. On the other hand, trust issues become a more important aspect for members of LMDH RS to do the group's activity.
\end{abstract}

\section{KEYWORDS}

Pandemic; Covid-19; Virus; Deforestation; Conservation; Community Forest

\section{INTRODUCTION}

Humanity has been facing various pandemics since 5,000 BC, such as the Hamin Mangha flu in China (ForestDigest, 2020). About a century ago, there was the Spanish Flu pandemic, in 1918-1919, which attacked humanity (Chamim, 2020) and claimed 50100 million lives (Karlsson et al., 2014). Concerns about the occurrence of an influenza pandemic have been raised by Garrett (2008) and it was estimated by the World Bank that such crisis would result in hundreds of billions of dollars in losses and kill tens of millions of lives.

Eventually, this concern first appeared in China in December 2019 with an increasing number of infected people in various parts of the world (Allam, 2020; Gorvett, 2020). This latest virus, identified as SARSCoV-2 (severe acute respiratory syndrome coronavirus 2), (Jeffries, 2020) is known by the abbreviation of COVID-19 (Corona Virus Disease-2019) (Gorvett, 2020). There are two main hypotheses of SARSCov-2's origin. The first hypothesis mentions that it is spread through animals until it reaches human (zoonosis) through pre-adaptation (Alanagreh et al., 2020; Andersen et al., 2020; Shereen et al., 2020; Wu et al., 2021). The second one is that the virus could escape from the laboratory and accidently reach humans, resulting in the epidemic (Wu et al., 2021). Until May 2021, this topic is still debatable with no clear evidence of the political interest between the Chinese and the Western society (Wu et al., 2021; Bloom 
et al., 2021). However, the Covid-19 is a very contagious disease (Mohhapotra et al., 2020) and has been identified in 213 countries (Google, 2021).

Further, the Covid-19 has evolved into different variants such as Apha, Beta, Delta, and Omicorn (Callaway, 2021; Okoth, 2021; WHO, 2021b; 2021c; BBC, 2021; BBC Indonesia, 2021). The Alpha variant can spread 50\% faster than the first Covid-19 outbreak variant, thus becoming a new wave of Covid-19 in Europe, North America, and the Middle East at the end of 2020 (Callaway, 2021). Then, the Delta variant was identified in the spring of 2021, and it is $60 \%$ more transmissible than the Alpha one (Callaway, 2021). Consequently, the delta variant has been reported in 96 countries in January 2021 (WHO, 2021b), becoming the dominant variant of Covid-19 (WHO, 2021a), and it was labeled as the Variant of Concern (VOC) by WHO in July 2021 (BBC Indonesia, 2021). In late November 2021, the Omicorn variant was identified in Africa (Callaway, 2021; Okoth, 2021; WHO, 2021c). In turn, at the end of 2021, the Omicorn variant became the VOC reported in 77 countries around the world (WHO, 2021c). The Omicorn variant has a larger mutation than the other variant, which tends to be more contagious than the Delta variant (WHO, 2021a), as has been shown in Singapore by Chong (2022) and confirmed by Dr. Tedros, the Chief of WHO (BBC, 2021). The Omicorn variant infected 900.000 people around the world in the end of December 2021 (BBC, 2021).

The Covid-19 pandemic is predicted to push 5.2\% (71 million) people to the extreme poverty gap in the Asian Continent by around 32 million people by the World Bank (Victoria, 2020) due to the lockdowns or social distancing policy that leaves people jobless (Kharas \& Dooley, 2021). The number of poor people in Indonesia is predicted by the World Bank to increase due to Covid-19 (Sugianto, 2020), with approximately \pm 48 million poor people from \pm 100 million people in total live near forest areas in Indonesian context (Asmin et al., 2019; Kuncoro \& Cahyani, 2018; Moeliono et al., 2017; Murti, 2018; Pambudi, 2020; Rakatama \& Pandit, 2020; Royer et al., 2018; Santika et al., 2019; Wright, 2011). Thus, people around or in the forest have become a vulnerable group to the Covid-19. On the other side, the Indonesia Government launched the SFP to alleviate poverty and preserve forest areas for the poor people who live in or nearby the forest (Wright et al., 2016; Moeliono et al., 2017; Firdaus, 2018; Fisher et al., 2018; Sahide et al., 2018; Susilo \& Nairobi, 2019).

This paper attempts to explain the connection between the Covid-19 pandemic and the SFP implementation through a new institutionalism framework by Victor Nee (2003). First, we examine the policy implemented during Covid-19 by the Ministry of Environment and Forest (MoEF) as the Indonesia Government representative, which is complemented by other party roles that support the forest communities during the Covid-19 pandemic. In the second part, we focus on the local context of communities that manage social forestry, especially the two communities categorized by the Social Forestry and Customary Forest Business Development or Bina Usaha Perhutanan Sosial dan Hutan Adat (BUSPHA), as a part of the Directorate General of Social Forest from the Ministry of Environment and Forestry as the model of the forest community in Indonesia. These two communities are Gunung Gajah Lestari Forest Farmer Group (KTH GGL) in Gongseng Village and Forest Village Community Rawa Sakti (LMDH RS) in Gambuhan Village, located in Pemalang, Indonesia.

\section{METHODS AND CONCEPTS}

The desk research method from various literature and electronic media is used to describe the relationship between deforestation and the emergence of pandemic or 
plague, which further impacts the people who live around the forest in Indonesia. We listed the copying strategies implemented by the MoEF and the forest people in general in the context of the Covid-19 pandemic in Indonesia. Additionally, we examined the SFP implementation in two communities in Pemalang, Central Java as the case study. We used a qualitative research method through in-depth interviews and participatory observation in KTH GGL and LMDH RS in January 2021. The main purpose of the interview was to understand and reveal their collective and business activity as a group. We interviewed 58 respondents as follows: two informants of Perum Perhutani, four informants of village officer, five informants of the forest community management, and 47 informants of forest community member.

This paper uses the concept of "new institutionalism" offered by Nee (2003), which looks at harmony/disharmony of rules/policies as institutional environment level in implementing SFP in the Covid-19 context in Indonesia by MoEF to organizational level on forest community, which is influenced by social relations reflected in the behavior of the members and the management of forest communities in social groups context. This paper tries to explain the relationship (Nee, 2003) between institutional environment, organization, and social groups at the individual level, especially in social groups and individuals in the KTH GGL and LMDH RS context. The scope of new institutionalism can be seen in Figure 1.

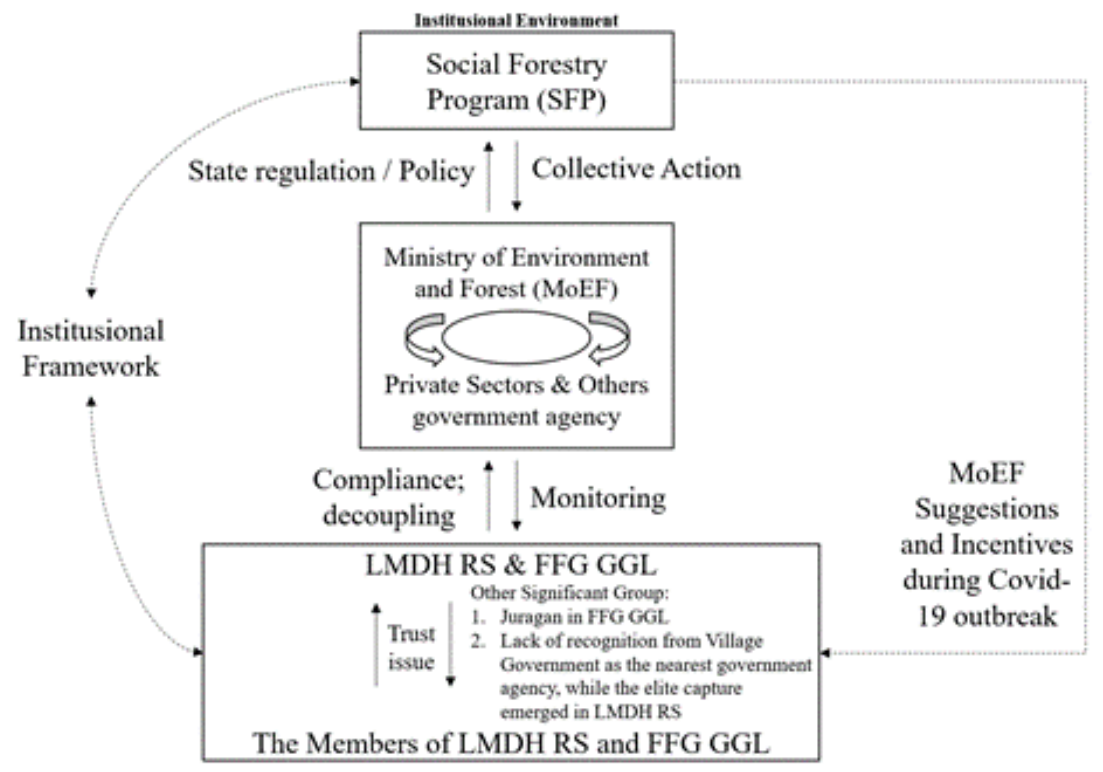

Figure 1. Scope of New Institutionalism Concept

[Source: Nee (2003), modified by authors)]

The harmony of the new institutionalism is called "coupling", such as policy or program which provides facilitation and interest as an implicit aspect by the government which needs to be legitimated by people and implemented in collective action by social groups level, which can be seen in individual behavior (Nee, 2003). So, if the individual of forest community has the same view and pursues the ultimate goal of social forestry, which refers to "SFP" in an institutional environment and can be 
called "coupling". On the other hand, Nee (2003) argued that there is an informal aspect of instances as norms or behavior that can cause socio-political instability or, in short, "decoupling". Coupling or decoupling can be seen both from the macro and micro level (Nee, 2003).

At the end of the paper, an opportunity will be presented for the challenges faced by communities around forests in Indonesia from the Covid-19 pandemic, which may require the attention of various parties concerned.

\section{DEFORESTATION, ZOONOSES, AND DIFFICULTIES OF COVID-19 FOR FOREST COMMUNITIES}

Environmental destruction, such as deforestation, impacts not only climate change but also natural disasters such as floods, landslides, etc. Another impact of environmental damage, especially deforestation, is the emergence of epidemics such as Covid-19 (Brancalion et al., 2020).

The Director of the United Nations Environment (United Nations) believes that "/.../ Nature is sending us a message with the pandemic corona virus. Failing to take care of the planet means not taking care of ourselves ..." (Rainforest Alliance, 2020a). This statement by Inger Andersen emphasizes that the destruction of ecosystems will also harm human life, through the emergence of new diseases such as Covid-19. Yet, human activity is a "catalyst" of changes in the face of the earth that can threaten the existence of about 1 million species of animals and plants and bring them to the brink of extinction (WWF, 2020).

The emergence of $60 \%-70 \%$ of infectious diseases from wildlife since the $1960 \mathrm{~s}$ in various parts of the world has been proven to be caused by the zoonosis ${ }^{1}$ process, as explained by Kate Jones, the head of Ecology and Biodiversity at UCL, England (Marco et al., 2020; Robins, 2012; Yuliardi, 2020; Vidal, 2020). Then, how can deforestation cause an epidemic? This is explained by Wolfe et al. (2005), who state that there are three risk factors for the emergence of infectious diseases by the zoonotic process, namely:

1. Diversity of wildlife microbes in an area,

2. Impact of environmental changes on the prevalence of pathogens in wild populations, and

3. Frequency of animal and human contact with zoonotic potential in wildlife reservoirs

Deforestation is sometimes followed by hunting wild animals and trading them either for consumption or domestication for various purposes, resulting in the conversion of forests (EcoHealth Alliance, 2019; Wolfe et al., 2005; Vidal, 2020). On the other hand, when animals lose their habitat, the forests continue to be eroded by the human activity (Vidal, 2020).

On the other hand, there are village communities around the forest that use bush meat as subsistence food, although there are not many such animals, meaning that those animals are sold in the black market in the city at higher prices due to their exoticism. This has led to an increase in the potential for intentional or unintentional human interaction with animals/wildlife, which can be the cause of the emergence of deadly infectious diseases for humanity (Wolfe et al., 2005; Vidal, 2020; WWF, 2020).

\footnotetext{
${ }^{1}$ The process of transmitting diseases from animals to humans through interactions especially with wildlife Siburian et al. (2022)
} 
Meanwhile, Professor Alesandra Nava (veterinarian) ${ }^{2}$ states that viruses that have the potential to become new epidemics for human life already exist and are waiting for their opportunities to interact with humans (Jordan \& Howard, 2020). Land conversion has occurred three centuries ago (EcoHealth Alliance, 2019) with the greatest potential of these viruses in tropical rainforests, which are home to millions of species that carry viruses, bacteria, and even parasites (WWF, 2020). With only 164,000 animals and humans, Professor Alesandra's team has discovered approximately 1,000 new viruses, pointing to forest exploitation, such as deforestation, as the main potential factor for new outbreaks (EcoHealth Alliance, 2019; Jordan \& Howard, 2020; WWF, 2020). In reality, it turns out that humans have converted tropical rain forests, such as the loss of $3 / 4$ of tropical rain forests in Africa (Standford University, 2020).

There are several zoonotic diseases, namely: coronavirus, rabies, Lyme disease, dengue fever, malaria, chikungunya, salmonella infection, Escherichia coli, HIV, west nile virus, zika, and swine flu, yellow fever, oropouche, SIV, ebola, viral nipah, SARS, rocky mountain spotted fever, leishmaniasis, sleeping sickness, babesiosis, leptospirosis, eccinococcus multiocularis (Rainforest Alliance, 2020a; Wilcox \& Ellis 2006).

There are several examples of the emergence of diseases identified by the WWF (2020) due to deforestation/environmental damage, leading to zoonosis:

Table 1. Examples of Cases of Disease due to Human Activities

\begin{tabular}{lllc}
\hline \multicolumn{1}{c}{ Causes of human activity } & Disease & Geographic distribution & \multicolumn{1}{c}{ Cases per year } \\
\hline $\begin{array}{l}\text { Deforestation; water } \\
\text { project }\end{array}$ & Malaria & $\begin{array}{l}\text { Tropical (America, Asia, and } \\
\text { Africa) }\end{array}$ & 350 million people \\
$\begin{array}{l}\text { Deforestasion; mining } \\
\begin{array}{l}\text { Disruption of forest } \\
\text { ecosystem }\end{array}\end{array}$ & $\begin{array}{l}\text { Rabies } \\
\text { Ebola }\end{array}$ & $\begin{array}{l}\text { Tropical } \\
\text { Africa }\end{array}$ & 35 thousand died \\
\hline
\end{tabular}

[Source: WWF (2020) and Suhartono (2020)]

The ebola virus was caused by people consuming chimpanzees from the forest in 1996 which, at that time, killed 21 people from 31 villages (Vidal, 2020). Moreover, there are several other zoonotic diseases such as the Nipah virus that first appeared in Malaysia in 1998 due to deforestation with intensive farming near tropical forests through manga that is eaten by pigs through saliva or bat urine (Jordan \& Howard, 2020).

There was also a case of a child consuming monkeys from the forest with his family, later getting a fever and dying (Vidal, 2020). Other studies suggest that the loss of tropical forests makes people more physically vulnerable to wild animals and the viruses they carry (Stanford University, 2020). In the current case of Covid-19, SARS, ebola, and Nipah virus are said to have the same animal carrying viruses, namely bats (WWF, 2020; Marco et al., 2020; Jordan \& Howard, 2020).

In the Covid-19 pandemic, the rate of global poverty will increase (WWF, 2020) in developing countries that lack social security. The forestry sector has faced a decline in exports/imports of wood and paper products (FAO, 2020) as well as non-timber forest products/NTFPs (Rainforest Alliance, 2020b). The impact of Covid-19 on the forestry sector can be seen during January-February 2020. There was a decrease in imports of wood and paper products in the USA (-6\%), Chile (-24\%), China (-20\%), New Zealand ($17 \%)$, South Korea (-16\%), Japan (-14\%), and Canada (-11\%) (FAO, 2020), whereas,

\footnotetext{
${ }^{2}$ Veterinarians who first studied Covid-19 in China on the wet market in Wuhan.

Siburian et al. (2022)
} 
almost 1 billion people depend on the forest (CPF, 2020). Additionally, small and medium forest enterprises contribute by $50 \%$ formal and informal workforce, most of which comes from tropical forest countries (FAO, 2020).

In the context of the ASEAN economy, Covid-19 causes a decline in the Gross Domestic Product (GDP) of ASEAN countries, such as $-1 \%$ in Singapore, Indonesia, which is estimated to decrease its GDP with the worst conditions - $0.4 \%$ (ASEAN, 2020). The impact of Covid-19 also affected the forestry sector in the production and trade of forestry products (FAO, 2020), whereas workers in the agriculture, fisheries, and forestry sectors of Indonesia were the largest proportion of 35.7 million people (ASEAN, 2020). In the context of Indonesian forestry sector by April 2020, Indonesia's export performance of processed wood fell by $10 \%$ and of round wood by $20 \%$ (Rahayu, 2020).

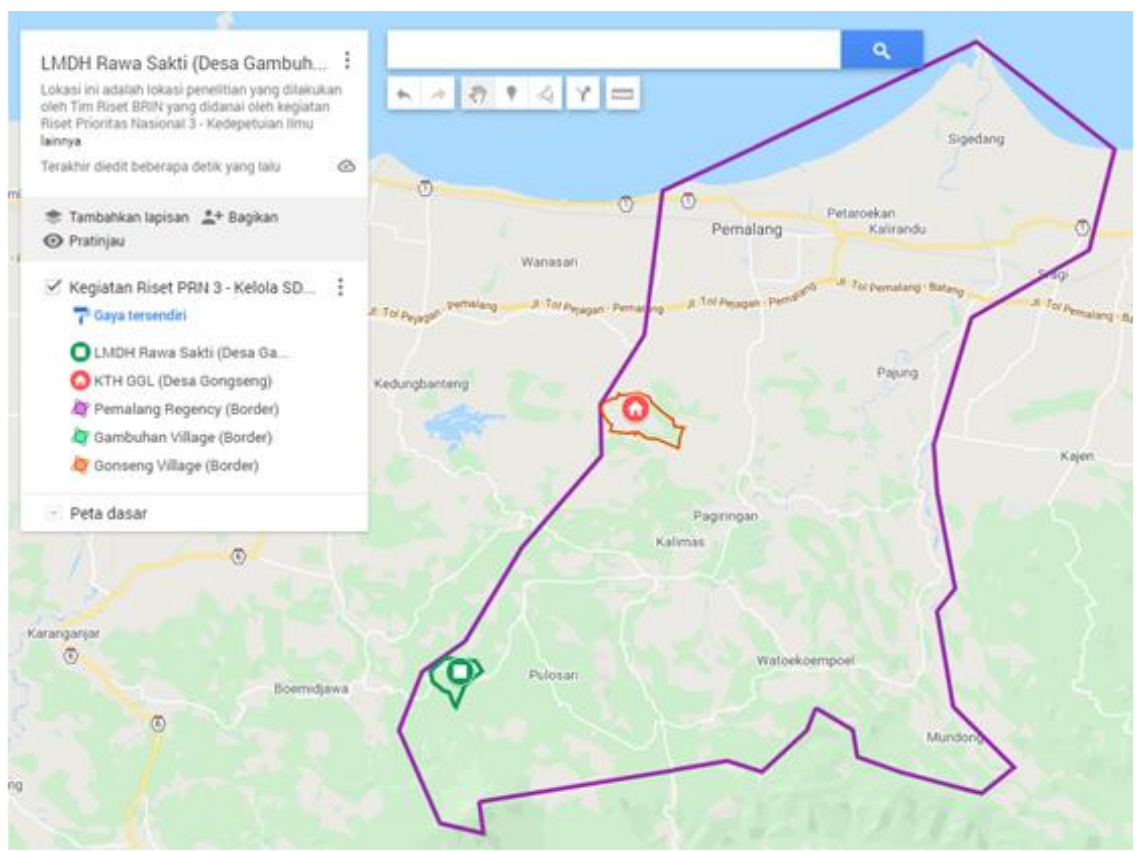

Figure 2. Location of FFG GGL and LMDH RS in Pemalang

[Source: Google Map (2021) ${ }^{3}$ ]

In the Indonesia context, Covid-19 also affects the social and economic life of forest communities, reducing their income by $90 \%$ for tourist activities (Supriyanto, 2020), such as for communities in Mount Halimun Salak National Park (TNGHS) (Tropis, 2020). More widely revealed the existence of Covid-19 causes delays in the distribution of products of the Social Forestry program and decreases visitors to the location (Rosdiana, 2020). The price of non-timber forest product commodities (NTFPs) has also decreased in Lukun Village, which sells rubber, and Sungai Tohor Village, Meranti Islands Regency, and Riau Province, which sells sago (Suryadi, 2020). On the other hand, the price of basic needs has risen in the Customary Law Community Mude Ayek Tabat Benawa in South Sumatera (Efriansyah, 2020). The next section will explain the

\footnotetext{
${ }^{3}$ This map can be accessed through Google Map (2021) with this link https://www.google.com/maps/d/u/0/ edit?mid=1nBzM8HiaQ9LV8svplsUSgs8S2acW1BP5\&usp=sharing created on 7 December 2021

Siburian et al. (2022)
} 
"institutional environment" by MoEF and the role of other stakeholders in facing this problem.

The social forestry program in Indonesia has five schemes of forest management (Forest Community, Forest Village, Community Forest Plantation, Customary Forest, and Forestry Partnership), which have been intensively implemented in Jokowi President Era since 2015 (Bakar et al., 2018; Moeliono et al., 2017; Royer et al., 2018; Susilo \& Nairobi, 2019). This program has published 6.411 certificates for groups that can manage their forests (Sesetyo, 2020). However, only several groups are categorized as model groups, such as KTH GGL and LMDH RS (BUPSHA, 2020a; 2020b). There are two forest community groups located in Pemalang Regency, Central Java. Although KTH GGL (Community Forestry) and LMDH RS (Forestry Partnership) are not in the same scheme of SFP, this paper tries to explain the connection between Covid-19 pandemic and the SFP implementation. The figure below is the research location where the FFG GGL is located in Gongseng Village, Radudongkal District, and LMDH RS is located in Gambuhan Village, Pulosari, District, in Pemelang Regency. The figure below is the research location where the FFG GGL is located in Gongseng Village, Radudongka District, and LMDH RS is located in Gambuhan Village, Pulosari, District, in Pemelang Regency.

\section{RESULT AND DISCUSSION}

\subsection{Institutional environment and the role of other stakeholders in the forest sector}

Institution, in short, is defined as a system related to formal and informal elements that govern social relations among the actors (Nee, 2003), and the most visible institution that reflects the "institutional environment" is state regulation or policy. There are several policies implemented by MoEF to support forest communities during the Covid-19.

In March 2020, after the first case of Covid-19 in Indonesia, MoEF purchased forest community products through IDR 780 million into 7,000 packages, which were distributed to medical personnel (ForestDigest, 2020; B-Oneindonesia, 2020; Ansyari, 2020). This policy has pushed forest farmers to improve their productivity while supporting the Indonesian Government to reduce the spread of the Covid-19 cases (ForestDigest, 2020; B-Oneindonesia, 2020; Ansyari, 2020).

The second policy was created in April 2020, when MoEF provided IDR 47 billion to give productive economic tool assistance, which becomes 470 productive economic tools for forest communities to survive in Covid-19 pandemic because the tool was believed to improve added value until $30 \%-40 \%$ of forest commodity (B-Oneindonesia, 2020; Syukra, 2020). Besides, MoEF has urged forest farmers to plant herbal plants (Hambali, 2020), and there was a campaign to to encourage Indonesians to consume herbal drinks produced by forest farmers (B-Oneindonesia, 2020).In the same month, MoEF prepared to provide around IDR 1.01 trillion to provide social assistance programs to people within and around forests; one of the activities included e-learning or remote training for forest communities and their companions (Fajardin, 2020; Kholisdinuka, 2020; KLHK, 2020 Sekretaris Kabinet RI, 2020). Other facilitation methods from MoEF to forest communities are loan services with a low interest, called Bang PeSoNa, to help communities start a forest business, with the budget around IDR 50 billion, while a forest community can apply for a loan of maximum IDR 50 million (ForestDigest, 2020; B-Oneindonesia, 2020). 
The third policy to support forest communities in Covid-19 by MoEF is to instruct the private sector which hold the timber forest utilization business license (Izin Usaha Pengelolaan Hasil Hutan Kayu - IUP-HHK) such as industrial forest (Hutan Tanaman Industril HTI) to enhance partnership with people (Sugiharto, 2020). The other policy is the implementation of e-learning, which involved around 1,581 participants to increase forest communities' competence and capacity in Indonesia (Hambali, 2020; Rosdiana, 2020). Support from the government to forest communities shows coupling from the institutional level (policy and budget) to the level of implementation at the "Governance" level, as mentioned by Nee (2003).

Other parties also contribute to providing social assistance to forest communities during the Covid-19 pandemic. One part of the country, BUMN ${ }^{4}$ in the forestry sector, also participated in providing assistance such as the Parengan $\mathrm{KPH}^{5}$ (Kesatuan Pengelolaan Hutan/Forest Management Unit), which distributed masks and takjilin 11 $\mathrm{BKPH}^{6}$ regions (Netpitu, 2020). Private participation in the alignment of Covid-19 handling in the context of forest village communities was also carried out by PT. SARBI ${ }^{7}$ distributed 600 food packages and masks in five locations ${ }^{8}$ (Sutisna, 2020), APP Sinar Mas $^{9}$, Royal Utama Group, Lestari Asri Jaya, and PT. Wana Mukti Wisesa ${ }^{10}$ carries out community empowerment and forestry partnerships in her work area (Hutagalung, 2020). IKA SKMA in South Sulawesi also delivered \pm 50 liters of forest honey to the Wahidin Sudirohusodo Hospital and handed over 120 food packages to the Head of Tammua Urban Village (Terkini News, 2020). Further, Banyuwangi City Police (Polresta) distributed food to communities around the ljen Mountain slope forest (Rozik, 2020). In the next section, we will provide examples of adaptative strategies to forest communities in Indonesia.

\subsection{Adaptation strategies for forest communities during the Covid-19 pandemic}

The previous section focused on the harmony of various elements of the country such as government, private sector, educational institutions, and public security institutions in Indonesia to support forest communities. This section will show that forest communities are not as weak as described in the previous section.

One element of the forest management community is indigenous community. Some strategies of indigenous people to survive in the midst of the Covid-19 pandemic include the following:

\footnotetext{
${ }^{4}$ State-owned enterprises.

${ }^{5}$ Forest Stakeholders Unit.

${ }^{6}$ Part of $\mathrm{KPH}$.

${ }^{7}$ PT. Sarbi Mahoeni Lestari.

${ }^{8}$ Namely, in the BP Berau Limited Watershed Rehab Area located in the Bintuni Bay Protection Forest in West Papua, in the watershed Rehab area of PT. Trubaindo Coal Mining, located at HPPBS under the Mulawarman University East Kalimantan Pusrehut stakeholders, in the Rehab Watershed area of PT. Nusa Halmahera Mineral located at HL Gunung Hamiding I and HPT Ake Ngabengan Gunung Tolu-tolu North Maluku, at the Rehab Watershed of PT. Jorong Barutama Grestone located in the Tahura Sultan Adam South Kalimantan Protected Forest and around the SARBI breeding center located in Majalengka, West Java.

${ }^{9}$ APP Sinar Mas stimulates the production of red ginger and honey and donates masks and groceries to the community.

${ }^{10}$ PT. LAJ and PT. WMW distributed Personal Protective Equipment (PPE) and herbal medicines from assisted farmers to medical personnel.
}

Siburian et al. (2022) 
Table 2. The Survival Strategy of Several Indigenous Peoples in the midst of the Covid19 Pandemic

\begin{tabular}{|c|c|c|c|}
\hline No & $\begin{array}{l}\text { Community/Indigenous } \\
\text { Community }\end{array}$ & Origin & Activity \\
\hline 1 & $\begin{array}{l}\text { Sekayu Darat } \\
\text { Indigenous Community }\end{array}$ & $\begin{array}{l}\text { Tempayung Village, } \\
\text { Central Kalimantan }\end{array}$ & Reject Bala Ritual \\
\hline 2 & $\begin{array}{l}\text { Enggros Indigenous } \\
\text { Community }\end{array}$ & Jayapura & $\begin{array}{l}\text { Put up portals on the road, set up } \\
\text { command posts, put up appeal } \\
\text { banners }\end{array}$ \\
\hline 3 & $\begin{array}{l}\text { Balinese Indigenous } \\
\text { Community }\end{array}$ & Bali & $\begin{array}{l}\text { Organizes activities that are } \\
\text { Scala and Noetic }\end{array}$ \\
\hline 4 & $\begin{array}{l}\text { Samin Indigenous } \\
\text { Community }\end{array}$ & $\begin{array}{l}\text { Around the Kenden } \\
\text { Mountains, Central } \\
\text { Java }\end{array}$ & $\begin{array}{l}\text { Committed to conserving forest } \\
\text { to mitigate food crisis by Covid- } \\
19\end{array}$ \\
\hline 5 & $\begin{array}{l}\text { East Nusa Tenggara } \\
\text { Indigenous Community }\end{array}$ & East Nusa Tenggara & $\begin{array}{l}\text { Traditional ceremonies prevent } \\
\text { the spread of Covid-19 }\end{array}$ \\
\hline 6 & $\begin{array}{l}\text { Customary Law } \\
\text { Communiy }\end{array}$ & South Sulawesi & $\begin{array}{l}\text { Familiarize washing hands and } \\
\text { feet before entering the house }\end{array}$ \\
\hline 7 & Jungle People & $\begin{array}{l}\text { Periphery of Bukit } \\
\text { Duabelas National } \\
\text { Park, Jambi }\end{array}$ & Choosing to return to the Forest \\
\hline 8 & $\begin{array}{l}\text { Baduy Indigenous } \\
\text { Community }\end{array}$ & Banten & $\begin{array}{l}\text { Held Kawalu ceremony which } \\
\text { prohibits outsiders to enter } \\
\text { forest areas }\end{array}$ \\
\hline 9 & $\begin{array}{l}\text { Mude Ayek Tebat } \\
\text { Benawa Indigenous } \\
\text { Community }\end{array}$ & South Sumatera & $\begin{array}{l}\text { The new oral rules for } \\
\text { newcomers to bath, wash their } \\
\text { clothes, and self-isolate for } 14 \\
\text { days }\end{array}$ \\
\hline
\end{tabular}

[Source: Efriansyah (2020); Nugraha (2020); Ramadhan (2020); Sutiawan (2020); Irianto (2020) the authors obtained]

These are just nine indigenous communities of Indonesian people, and other indigenous people might have their own ceremony, tradition, or other activities to reduce the spread of the Covid-19. Some tried to pray in rituals or ceremonies, while others used activities such as Customary Law Community in South Sulawesi, Baduy Indigenous Community in Banten, and Mude Ayek Tebat Benawa in South Sumatera. Even though there are no clear harmonization data between the indigenous communities and the government's interest to handle the Covid-19, at least the listed activities above show harmonization or coupling at the social group level, especially in indigenous communities with the institutional environment that supports them during the Covid-19.

An important aspect of forest communities is "economic" aspect mentioned in the third section that reduces income of the forest farmers. In contrast, several communities have tried to survive even to get the chance of the Covid-19 pandemic. First, the commodities planted by forest farmers in social forestry program can be used to fulfill nutritional needs for forest farmers' families, while the price of the basic needs is rising, such as Mude Ayek Tebat Benawa Indigenous Community (Efriansyah, 2020) and several KTH ${ }^{11}$ in Bogor (Media Indonesia, 2020). In other words, from SFP, the farmers in KTH or forest community minimum can use the crops for subsistence

\footnotetext{
${ }^{11}$ Forest Farmers Group; KTH Babakan Setu, KTH Lio Maju, KTH lebak Sawo, dan KTH Barokah Lio. Siburian et al. (2022)
} 
purposes, while they can still sell the crops to gain some money. The second strategy is coupling with the MoEF policy that urged forest farmers to plant the herbs that help the immune system (Hambali, 2020). KTH Giri Senang in Bandung tried to innovate their commodity to plant red ginger together with coffee (DimensiNews, 2020). Different from KTH Giri Senang in Bandung, KTH Serba Usaha in Merapi I, in Boyolali, produce fried onion, which is believed to improve the immune system (Paramita, 2020). Finally, another strategy was carried out in the collaboration between the private sector (APP Sinar Mas) and the IUPHHK-HTI Guided Village of PT. Namely, Wirakarya Sakti in Jambi increased commodity productivity, especially in ginger and honey. This collaboration between the private sector and the community was built in accordance with the harmony/coupling of the Covid-19 handlers announced by the Government of Indonesia (Nee, 2003).

The development of herbal communities is not only beneficial for communities at the local level but should also be seen as a national asset to be developed at the national level. Indonesia already has various capital to develop herbal commodity markets ranging from commodity types (such as honey, red ginger, to coffee), labor availability, and the size of manageable forest areas.

The alignment of forest activities in Indonesia due to Covid-19 stimulates technology usage for the forest community through e-learning held by MoEF and touches forest community in the corners of Indonesia (Awaluddin, 2020). although the implementation of e-learning cannot reach the expectation, it touched forest farmers and introduced them to technology usage as a first step for further development.

Finally, in regard to the weakness of the new institutionalism concept, we tried to examine the specific and explicit SFP policy implementation by MoEF to handle Covid19 in two forest farmer model groups on SFP in Pemalang as case studies. Unlike KTH Giri Senang in Bandung, they harmonized/coupled with the policy from MoEF, making the actual situation in both KTH GGL and LMDH RS groups more complex. The complexity of the SFP policy implementation during Covid-19 will be presented in the next section.

\subsection{Decoupling of forest community: dependency trap and knowledge blockage as the context in Pemalang}

KTH GGL in Gongseng Village, Pemalang, agrees with the advice by MoEF to plant the herbs (Hambali, 2020), although their primary commodity is the "corn". We identified the coupling in KTH GGL with MoEF's advice to plant the herbal commodity. If we accumulate a percentage of the commodities which contains "ginger" was $81.81 \%$ of the total informants who wanted to plant "ginger" and the others commodity as alternative commodity to enhance their income besides their plant corn. We can see this situation in Figure 2.

Further, we identified the informants' confidence level for these alternative commodities in KTH GGL, finding that $30.8 \%$ of the informants were confused with the new commodities, while $38.5 \%$ of the informants wanted to try the alternative commodity despite their lack of capital to buy the seed of the new commodity, especially ginger. Thus, we need to know why the informants in KTH GGL lack capital to plant new commodities. 
Based on the data we gathered in KTH GGL, many people in Gongseng Village tended to borrow the capital from "Juragan," "making the farmers deposit their harvest to them. Thus, the prices of fertilizer and pesticide are higher for farmers who borrow capital from Juragan. There is a gap between the original and borrowing price of fertilizer and medicine for corn plantation, which could reach IDR 864,000.00/hectare that is charged to the farmers who borrow the money from Juragan.

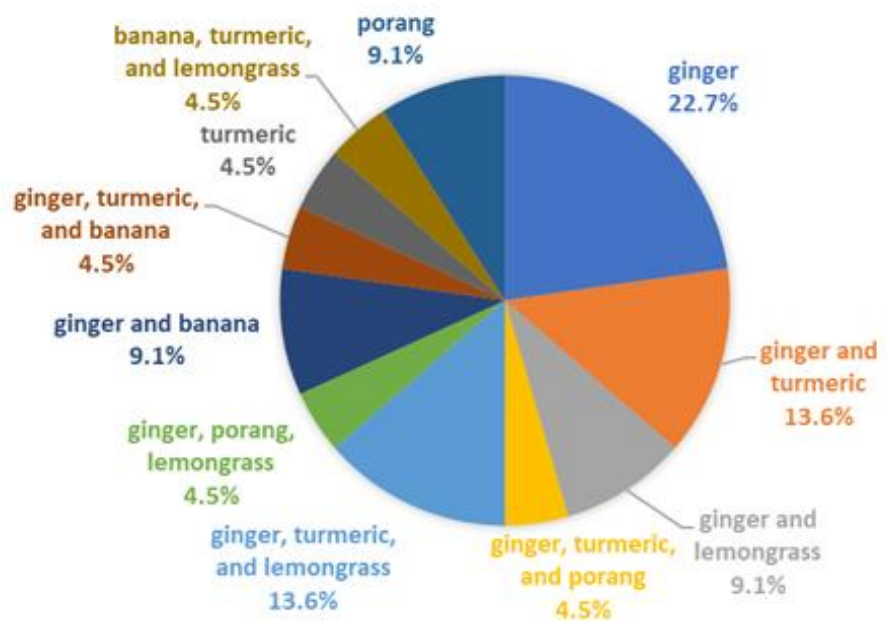

Figure 3. Alternative Commodity that Coupling with MoEF's Advice [Source: Primary data processed by authors]

So, when the harvest comes, the farmers do not gain the money directly after depositing their harvest to Juragan, but the "value" of the money is reduced after it is cut by a more expensive fertilizer and pesticides price determined by Juragan. Juragan also determined the quarterly price of the corn at the farmers' level, where they make profit of more or less IDR 20,000.00/quarter between they buy it from farmer and sell it to the corporation. This is the reason why the informants of members of KTH GGL have a problem to buy new commodity seeds, and it is maintained through low income for planting corn by Juragan. Then, we asked the informants why they still wanted to plant the corn.

$95.8 \%$ of the informants, members of KTH GGL, said they still wanted to plant the corn due to the ease of capital to plant, marketing, and life loans to survive. Life loans become an essential reason for people in Gongseng Village, where farmers have no money for education or health expense, which is why they can borrow from the Juragan with one requirement, that is has a cornfield and the harvest as the colleteral guarantee. This is the dependency trap, which makes them need more courage and energy to get out of the decoupling situation with MoEF advice.

In the LMDH RS context related to e-learning issues that was launched by MoEF in 2020 to empower capacity and competence of the forest community and forest

\footnotetext{
${ }^{12}$ Juragan is the person who lend their capital (money) to the farmers (include the members of KTH GGL) who want to plant the "corn". They has role to supply the fertilizer and pesticide, when the harvest season arrive so the farmers must deposit their harvest to the Juragan. The system is not the crop-sharing, but Juragan buy the harvest from farmers who lend to them where the Juragan determine the "price", and after that the Juragan sell the gathered harvest to the corporation.
}

Siburian et al. (2022) 
community companion (Hambali, 2020; Rosdiana, 2020). Based on the data, LMDH RS have participated in e-learning in 2020 by MoEF, but it did not empower capacity and competency of LMH RS as forest community as one entity or one group. As most representatives of $\mathrm{LMDH}$ RS in many forests community training both form MoEF or other stakeholders tend to be attended by the same person from management of LMDH $\mathrm{RS}$ or elite capture. In short, there is a decoupling in e-learning activity between MoEF interest and implementation in LMDH RS context.

Moreover, the management of LMDH RS and the informants as the members of $\mathrm{LMDH}$ RS runs the activities in this groups individually. There are rarely routine activities between management and members of LMDH RS, where the distributed information tends to be old and less comprehensive. On the other hand, the informant of the management of LMDH RS sees routine activities between management and members as ineffective and inefficient to LMDH RS cash flow, because “...many heads in meeting will come many thoughts ... (that makes difficult situation to pick a solution, based on depth interview one of the managements of LMDH RS)." In the observation by Focus Group Discussion/FGD, authors found many plans explained by one informant of management on behalf of LMDH RS just found out by the members in that FGD. This happens due to several people in management of LMDH RS who plan and determine the solution for this group.

In the LMDH RS context, the goal of the e-learning may be deliverd and competences in LMDH RS may be enhanced, but it did not increase the LMDH RS as a group of forest community in SFP. In addition, there is one aspect that makes members in LMDH RS run their activities in individually, that is "distrust," especially of the management of LMDH RS. The "one" of the LMDH RS is felt and believed by several members, and other management LMDH RS use his/her authority to increase personal capital, including "money" or "knowledge."

From these facts about interaction between the LMDH RS management and their members, we can see the "elite capture"13 align with other studies (Asmin et al., 2019; Essougong et al., 2019; Qurniati et al., 2019; Moeliono et al., 2017). In our case studies, the elite obtained more information to empower their capacity but did not distribute it to the members of LMDH RS as decoupling of e-learning by MoEF. This is the knowledge blockage less touched by e-learning from MoEF if they just delivered the knowledge to elite of the groups. Additionally, the decoupling is strengthened by distrust between management and members of the LMDH RS.

\section{CONCLUSION}

Reviewing new institutionalism based on data obtained shows that the form or tendency of a policy is strongly influenced by the role of political actors, especially MoEF as the government actor. The policy that arises in the institutional environment becomes an atmosphere that can influence other actors to act and behave in conditions that emerge either "in harmony/coupling" in Indonesian national context. In practice, there is a harmony/coupling between Covid-19 and the community around the forest from policies that support the community. However, the harmony in Indonesia is less organized or occurs sporadically.

\footnotetext{
${ }^{13}$ Elite capture is chances or benefits in participation process to empower people to improve community ability which is actually obtained by elites, leaders, administrators of a group (Rakatama et.al, 2020; Qurniati et.al, 2019).
}

Siburian et al. (2022) 
As a result, although the tendency of the SFP in national context aligns with the social group level, there is a unique and complex situation, especially at the social group level, and their members are the individuals which are not really examined by new institutionalism by Nee (2003). Further, this unique and complex situation between the members and the management of the social groups is the cornerstone for the social groups level to implement and reach the "collective action". The dynamics of social groups' level, especially the relation between management and the members that need to be examined for SFP implementation in Indonesia. Distrust between the members and the management becomes an important aspect, such in LMDH RS where the elite capture happens and the members do their activities individually, which disables them from the collective action. Moreover, other "actors" need to be considered because they could influence the situation such as Juragan in KTH GGL.

Then, in the practical domain, Covid-19 presents a copying strategy in culture and socio-economy to get an opportunity of commodities related to human immunity. This opportunity needs to be developed by the government together with the public and the private sector to fulfill Indonesia's large local market, aiming at the global market. Further, technological application such as e-learning becomes the stepping stone that can be further developed through continuous learning related to information technology and forest management techniques.

Author Contributions: Robert Siburian, Dicky Rachmawan, and Fanny Henry Tondo contributed equally as the main contributor of this paper. All authors read and approved the final paper.

Conflicts of Interest: The authors declare no conflict interest.

Acknowledgments: This research is sponsored by the Social Science and Humanities Deputy of Indonesian Institute of Science (IPSK LIPI, whose name is changed into Research Organization of Social and Humanities, National Research and Innovation Agency-IPSH BRIN) based on approvement by the Head of Research Center for Society and Culture (PMB BRIN). Thank you very much to Prof. Dr. Ahmad Najib Burhani and Prof. Dr. Tri Nuke Pudjiastuti for the instructions and help given to writers. We are also thankful to Mr. Danang Kuncoro, BUPSHA Team, and to all informants involved in this research activity, especially in Gongseng and Gambuhan Village, Pemalang Disctric.

\section{REFERENCES}

Alanagreh, L. A., Alzoughool, F., \& Atoum, M. (2020). The human coronavirus disease COVID-19: Its origin, characteristics, and insights into potential drugs and its mechanisms.

Pathogens,

$9(5)$,

331. https://doi.org/10.3390/pathogens9050331

Allam, Z. 2020. The First 50 days of COVID-19: A Detailed Chronological Timeline and Extensive Review of Literature Documenting the Pandemic. Surveying the Covid-19 Pandemic and its Implications: 1-7. doi: 10.1016/B978-0-12-8243138.00001-2

Andersen, K. G., Rambaut, A., Lipkin, W. I., Holmes, E. C., \& Garry, R. F. (2020). The proximal origin of SARS-CoV-2. Nature Medicine, 26(4), 450-452. https://doi.org/10.1038/s41591-020-0820-9

Ansyari, Syahrul. (2020). Hadapi Corona, Kementerian LHK Akan Bagi-bagi Produk Petani Hutan. Vivanews.com. https://www.vivanews.com/berita/ nasional/47073-hadapi-corona-kementerian-lhk-akan-bagi-bagi-produkpetani-hutan 
ASEAN. (2020). Economic Impact of Covid-19 Outbreak on ASEAN. ASEAN Policy Brief. April 2020

Asmin, F., Darusman, D., Ichwandi, I., \& Suharjito, D. (2019). Mainstreaming communitybased forest management in west sumatra: Social forestry arguments, support, and implementation. Forest and Society, 3(1), 77-96. https://doi.org/10.24259/fs.v3i1.4047

Awalludin. (2020). Belajar Sambil Mendapatkan Solusi, in B. Supriyanto et.al (eds) (2020). Catatan Belajar Virtual Pendamping dan Petani Hutan Sosial. Jakarta: Kementerian Linkungan Hidup dan Kehutanan. Accessed from http://pkps.menlhk.go.id/assets/file/literatur/20210522091524-literatursalam-lima-jari.pdf

Bakar, S.N., Awang, S.E., \& Efransjah (Eds.). (2018). Status Hutan dan Kehutanan Indonesia 2018. Kementerian Lingkungan Hidup dan Kehutanan Republik Indonesia.

BBC Indonesia. (2021). Varian baru yang lebih menular perlu diwaspadai, Covid dapat mencapai 400.000 kasus di Indonesia. BBC Indonesia. https://www.bbc.com/indonesia/indonesia-59464740

BBC. (2021). Covid: Omicron and Delta driving tsunami of cases - WHO. BBC. https://www.bbc.com/news/world-59822209

Bloom, J. D., Chan, Y. A., Baric, R. S., Bjorkman, P. J., Cobey, S., Deverman, B. E., ... \& Relman, D. A. (2021). Investigate the origins of COVID-19. Science, 372(6543), 694-694. https://doi.org/10.1126/science.abj0016

B-Oneindonesia. (2020). KLHK Bantu Petani Tingkatkan Produksi di Tengah Pandemi Corona. B-Oneindonesia. http://b-oneindonesia.co.id/berita/31/03/2020/ klhk-bantu-petani-tingkatkan-produksi-di-tengah-pandemi-corona/

Brancalion, P. H., Broadbent, E. N., de-Miguel, S., Cardil, A., Rosa, M. R., Almeida, C. T., ... \& Almeyda-Zambrano, A. M. (2020). Emerging threats linking tropical deforestation and the COVID-19 pandemic. Perspectives in Ecology and Conservation, 18(4), 243-246. https://doi.org/10.1016/j.pecon.2020.09.006

BUPSHA. (2020a). Profil Kelompok KTH Gunung Gajah Lestari [PowerPoint Slides]. BUSPHA.

BUPSHA. (2020b). Profil LMDH Rawa Sakti[PowerPoint Slides]. BUSPHA.

Callaway, E. (2021). Beyond Omicron: what's next for COVID's viral evolution. Nature 600, 204-207 (2021), 7 December 2021, doi: https://doi.org/10.1038/d41586021-03619-8. Accessed from https://www.nature.com/articles/d41586-02103619-8

Chamim, M. (2020). Influenza yang meneror dunia. Forestdigest. https://www.forestdigest.com/detail/613/influenza-yang-meneror-dunia

Chong, C. (2022). Omicron versus Delta: What we know so far about the Covid-19 variants. The Straits Times. https://www.straitstimes.com/singapore/health/ omicron-versus-delta-what-we-know-so-far

CPF. (2020). Towards sustainability: forest solutions in response to the COVID-19 pandemic. Collaborative Partnership on Forests. Retrieved from https://redd.unfccc.int/uploads/2_234_cpf_statement_on_covid_120ct2020_ small.pdf

De Royer, S., Van Noordwijk, M., \& Roshetko, J. M. (2018). Does community-based forest management in Indonesia devolve social justice or social costs?. International Forestry Review, 20(2), 167-180. https://doi.org/10.1505/14655481882 


\section{9}

Di Marco, M., Baker, M. L., Daszak, P., De Barro, P., Eskew, E. A., Godde, C. M., ... \& Ferrier, S. (2020). Opinion: Sustainable development must account for pandemic risk. Proceedings of the National Academy of Sciences, 117(8), 38883892. https://doi.org/10.1073/pnas.2001655117

DimensiNews. (2020). Kisah sukses petani hutan saatpandemi Covid-19. DimensiNews. https://www.dimensinews.co.id/65128/kisah-sukses-petani-hutan-saatpandemi-covid-19.html

EcoHealth Alliance. (2019). Infectious Disease Emergence and Economics of Altered Landscapes. EcoHealth Alliance.

Efriansyah, E. (2020). Pengelola Hutan Adat Belajar Virtual. In Supriyanto, B., Rosdiana, E., Suradiredja, D.Y., Dewi, S.U., \& Hidayat, B. (Eds.), Catatan Belajar Virtual Pendampingan dan Petani Hutan Sosial. Kementerian Lingkungan Hidup dan Kehutanan.

Fajardin, M. A. (2020). Cara Kementerian LHK Bantu Masyarakat Sekitar Hutan yang Terdampak Corona. Sindonews. https://nasional.sindonews.com/read/2504/ 15/cara-kementerian-lhk-bantu-masyarakat-sekitar-hutan-yang-terdampakcorona-1587020676

FAO. 2020. The Impacts of Covid-19 on the forest sector: How to Respond?. Food and Agriculture Organization Retrieved from https://www.fao.org/3/ca8844en/ CA8844EN.pdf

Firdaus, A.Y. (2018). Panduan Praktis Penerapan Kebijakan Perhutanan Sosial: Kerangka Percepatan Reformasi Tenurial Hutan. CIFOR. https://doi.org/10.17528/cifor/006856

Fisher, M. R., Moeliono, M., Mulyana, A., Yuliani, E. L., Adriadi, A., Judda, J., \& Sahide, M. A. K. (2018). Assessing the new social forestry project in Indonesia: recognition, livelihood and conservation?. International Forestry Review, 20(3), 346-361. https://doi.org/10.1505/146554818824063014

ForestDigest. (2020). 10 wabah global terburuk di era modern. ForestDigest. https://www.forestdigest.com/detail/525/10-wabah-global-terburuk-di-eramodern

Garrett, T. A. (2008). Pandemic economics: The 1918 influenza and its modern-day implications. Federal Reserve Bank of St. Louis Review, 90(2), 1-19. https://doi.org/10.20955/r.90.74-94

Google Map. (2020) LMDH Rawa Sakti (Desa Gambuhan) dan KTH Gunung Gajah Lestari (Desa Gongseng). https://www.google.com/maps/d/u/0/edit?mid=1nBzM8Hia Q9LV8svplsUSgs8S2acW1BP5\&usp=sharing

Google. (2021). Virus Corona (COVID-19). Retrieved from https://news.google.com/covid19/map?hl=id\&gl=ID\&ceid=ID\%3Aid

Gorvett, Z. (2020). Virus Corona: perselisihan di balik proses penamaan virus baru. BCC News Indonesia. https://www.bbc.com/indonesia/vert-fut-51555049

Hambali. 2020. Penanganan Covid-19, Menteri Siti Imbau Petani Hutan Produksi Tanaman Herbal. Okezone, 27 April 2020, accessed from https://nasional.okezone.com/read/2020/04/27/337/2205586/penanganancovid-19-menteri-siti-imbau-petani-hutan-produksi-tanaman-herbal.

Hutagalung, R. (2020). Peran Serta Pemegang IUPHHK-HTI Memberdayakan Masyarakat pada Masa Pandemi Covid-19. KLHK. https://www.fordamof.org/berita/post/7068-peran-serta-pemegang-iuphhkhti-memberdayakan- 
masyarakat-pada-masa-pandemi-covid19

Irianto, W. (2020). Orang Rimba Kembali ke Hutan untuk Social Distancing karena Covid-19. Times Indonesia. https://www.timesindonesia.co.id/read/news/ 265611/orang-rimba-kembali-ke-hutan-untuk-social-distancing-karenacovid19

Jeffries, B. (2020). The Loss of Nature and The Rise of Pandemics: Protecting Human and Planetary Health. WWF International.

Jordan, L. \& Howard, E. (2020). Breaking down the Amazon: how deforestation could drive the next pandemic. Greenpeace. https://unearthed.greenpeace.org/ 2020/04/24/deforestation-amazon-next-pandemic-covid-coronavirus

Karlsson, M., Nilsson, T., \& Pichler, S. (2014). The impact of the 1918 Spanish flu epidemic on economic performance in Sweden: An investigation into the consequences of an extraordinary mortality shock. Journal of Health Economics, 36, 1-19. https://doi.org/10.1016/j.jhealeco.2014.03.005

Kharas, H. \& Dooley, M. (2021). Extreme Poverty in the Time of Covid-19. Brookings Institution. Retrieved from https://www.brookings.edu/wpcontent/uploads/2021/06/Extreme-poverty-during-the-time-of-COVID-19.pdf

Kholisdinuka, A. (2020). Bantu Petani Hutan Terdampak Corona, KLHK Alokasikan Rp 1,01 Triliun. Detiknews. https://news.detik.com/berita/d-4978974/bantupetani-hutan-terdampak-corona-klhk-alokasikan-rp-101-triliun

KLHK. 2018. Dampak Perhutanan Sosial: Perspektif Ekonomi, Sosial, dan Lingkungan. Yogyakarta: Direktorat Jenderal Perhutanan Sosial dan Kemitraan Lingkungan KLHK.

KLHK. 2020. KLHK Alokasikan Rp 1,01 Triliun untuk Bantu Masyarakat dan Petani Hutan Terdampak Corona. SIARAN PERS Nomor: SP. 146 /HUMAS/PP/HMS.3/4/2020, 16 April 2020.

Kuncoro, M., \& Cahyani, D. F. (2018). Performance of social forestry on farmers' revenues: lessons from Yogyakarta and Lampung, Indonesia. The Business \& Management Review, 9(4), 275-289.

Media Indonesia. (2020). Kelompok Tani Hutan Tetap Panen di Tengah Wabah Covid19. Media Indonesia. https://mediaindonesia.com/read/detail/300468kelompok-tani-hutan-tetap-panen-di-tengah-wabah-covid-19

Moeliono, M., Thuy, P. T., Bong, I. W., Wong, G. Y., \& Brockhaus, M. (2017). Social forestry-why and for whom? A comparison of policies in vietnam and Indonesia. Forest and Society, 1(2), 78-97. https://doi.org/10.24259/fs.v1i2.2484

Mohapatra, et.al. 2020. The recent challenges of highly contagious COVID-19, causing respiratory infections: Symptoms, diagnosis, transmission, possible vaccines, animal models, and immunotherapy. Chem Biol Drug Des: 1-22. doi: 10.1111/cbdd.13761.

Murti, H.A. (2018). Perhutanan Sosial bagi Keadilan Masyarakat dan Pengurangan Kemiskinan. Jurnal Analisis Kebijakan 2(2), 62-75.

Nee, V. (2003). New Institutionalism, Economic and Sociology (CSES Working Paper Series Paper \#4). Cornel University. https://www.economyandsociety.org/wpcontent/uploads/2013/08/wp4_nee_03.pdf

Netpitu. (2020). Perhutani Peduli Masyarakat Terdampak Virus Covid-19 Bagi Masker dan Takjil. Netpitu. https://netpitu.com/baca/20/05/2020/perhutani-pedulimasyarakat-terdampak-virus-covid-19-bagi-masker-dan-takjil/ 
Nugraha, A. S. (2020). Kearifan Lokal dalam Menghadapi Pandemi Covid-19: Sebuah Kajian Literatur. Sosietas, 10(1), 745-753.

Okoth, D. (2021). From Delta to Omicron: 2021 in review. SciDev. https://www.scidev.net/global/news/from-delta-to-omicron-2021-inreview/?gclid=CjwKCAiAxJSPBhAoEiwAeO_fPFRDS4XznLCdFuyrUB3LDnwx9le YBRV_2ruXWyzrn6E1le85-fi2RoCefUQAvD_BwE

Pambudi, A. S. (2020). The Development of Social Forestry in Indonesia. The Journal of Indonesia Sustainable Development Planning, 1(1), 57-66. https://doi.org/10.46456/jisdep.v1i1.11

Paramita, A. (2020). Survival masyarakat lereng timur Merapi dalam menghadapi pandemi Covid-19. KLHK. http://ksdae.menlhk.go.id/info/8074/survivalmasyarakat-lereng-timur-merapi-dalam-menghadapi-pandemi-covid-19.html

Qurniati, R., Darmawan, A., Utama, R.B., \& Inoue, M. (2019). Poverty distribution of different types of forest-related communities: case study in wan abdul rachman forest park and mangrove forest in sidodadi village, lampung province, Indonesia. Biodiversitas, 20 (11): 3153-3163. DOI: 10.13057/biodiv/d201107

Rahayu, A. C. (2020). Industri kayu olahan tertekan Corona, APHI dorong pemulihan di awal semester //. Kontan. https://industri.kontan.co.id/news/industri-kayuolahan-tertekan-corona-aphi-dorong-pemulihan-di-awal-semester-ii

Rainforest ALLIANCE. 2020a. Deforestation and Pandemics. In http://www.rainforestalliance.org. Accessed on 17 May 2020.

Rainforest ALLIANCE. 2020b. Covid-19 pandemic: live updates from our field colleagues and frontline partners. In http://www.rainforest-alliance.org. Accessed on 17 May 2020.

Rakatama, A., \& Pandit, R. (2020). Reviewing social forestry schemes in Indonesia: Opportunities and challenges. Forest Policy and Economics, 111, 1-13. https://doi.org/10.1016/j.forpol.2019.102052

Ramadhan, R. (2020). Nasib Masyarakat Adat di Tengah Pandemi Covid-19. Asumsi. https://www.asumsi.co/post/nasib-masyarakat-adat-di-tengah-pandemicovid-19

Robins, J. (2012). The ecology of disease. The New York Times. https://www.nytimes.com/2012/07/15/sunday-review/the-ecology-ofdisease.html

Rosdiana, E. (2020). Semangat Baru di Masa Pandemi. In Supriyanto, B., Rosdiana, E., Suradiredja, D.Y., Dewi, S.U., \& Hidayat, B. (Eds.), Catatan Belajar Virtual Pendampingan dan Petani Hutan Sosial. Kementerian Lingkungan Hidup dan Kehutanan.

Rozik, R. (2020). Aksi kemanusiaan, polresta banyuwangi bagikan sembako ke masyarakat hutan. Nusa Daily. https://nusadaily.com/regional/aksikemanusiaan-polresta-banyuwangi-bagikan-sembako-ke-masyarakathutan.html

Sahide, M. A. K., Jusuf, Y., Alam, S., Millang, S., Mahbub, A. S., Bachtiar, B., ... \& Yahya, N. H. (2018). Kajian Dampak Perhutanan Sosial Provinsi Sulawesi Selatan. Fakultas Kehutanan, Universitas Hasanuddin.

Santika, T., Wilson, K. A., Budiharta, S., Kusworo, A., Meijaard, E., Law, E. A., ... \& Struebig, M. J. (2019). Heterogeneous impacts of community forestry on forest conservation and poverty alleviation: Evidence from Indonesia. People and Nature, 1(2), 204-219. https://doi.org/10.1002/pan3.25 
Sekretaris Kabinet RI. (2020). KLHK Alokasikan Rp 1,01 Triliun Bantu Masyarakat dan Petani Hutan Terdampak Covid-19. Sekretaris Kabinet RI. https://setkab.go.id/klhk-alokasikan-rp-101-triliun-bantu-masyarakat-danpetani-hutan-terdampak-covid-19

Shereen, M. A., Khan, S., Kazmi, A., Bashir, N., \& Siddique, R. (2020). COVID-19 infection: Origin, transmission, and characteristics of human coronaviruses. Journal of Advanced Research, 24, 91-98. https://doi.org/10.1016/j.jare.2020.03.005

Standford University. (2020). Forest loss could make diseases like COVID-19 more likely, according to study. World Economic Forum. https://www.weforum.org/agenda/2020/04/forest-loss-diseases-covid19coronavirus-deforestation-health

Sugianto, D. (2020). Bank Dunia Sebut 115 juta Orang RI Rentan Kembali Miskin. Detik. https://finance.detik.com/berita-ekonomi-bisnis/d-4878935/bank-duniasebut-115-juta-orang-ri-rentan-kembali-miskin

Sugiharto, S. (2020). Pandemi COVID-19, KLHK Minta Perusahaan HTI Perkuat Kemitraan Masyarakat. Agro Indonesia. http://agroindonesia.co.id/2020/05/ pandemi-covid-19-klhk-minta-perusahaan-hti-perkuat-kemitraan-masyarakat

Suhartono, A. (2020). Sejak 2009, WHO 6 Kali Deklarasikan Status Darurat Global Akibat Virus. iNews. https://www.inews.id/news/internasional/sejak-2009who-6-kali-deklarasikan-status-darurat-global-akibat-virus

Supriyanto, B. (2020.) Perhutanan Sosial Perekat Ekonomi Rakyat dan Ekologis Hutan di Pandemi Covid-19. Rimbaindonesia. https://rimbaindonesia.id/artikelutama/perhutanan-sosial-perekat-ekonomi-rakyat-dan-ekologis-hutan-dipandemi-covid-19

Suryadi, S. (2020). Tak terserap pasar, produksi sagu sungai tohor lesu di masa pandemi. Mongabay. https://www.mongabay.co.id/2020/05/22/tak-terserappasar-produksi-sagu-sungai-tohor-lesu-di-masa-pandemi/

Susetyo, P. D. (2020). Kualitas Perhutanan Sosial. Agroindonesia. http://agroindonesia.co.id/2020/04/kualitas-perhutanan-sosial/

Susilo, Y. S., \& Nairobi (2019). Dampak Perhutanan Sosial Terhadap Pendapatan Masyarakat. ISEI Economic Review, 3(1), 16-27.

Sutiawan, I. (2020). Beragam Cara Masyarakat Adat Hadapi dan Cegah Wabah Covid19. Gatra. https://www.gatra.com/detail/news/478670/kebencanaan/ beragam-cara-masyarakat-adat-hadapi-dan-cegah-wabah-covid-19

Sutisna, A. (2020). Di Tengah Pandemi Covid-19, PT SARBI Membagikan Sembako dan Masker kepada Masyarakat Sekitar Hutan. Harian Nasional News. http://www.harnasnews.com/ditengah-pandemi-covid-19pt-sarbimembagikan-sembako-dan-masker-kepada-masyarakat-sekitar-hutan

Syukra, R. (2020). Di Tengah Pandemi Covid-19, KLHK Dorong Ekonomi Lokal Melalui Perhutanan Sosial. Investor. https://investor.id/business/di-tengah-pandemicovid19-klhk-dorong-ekonomi-lokal-melalui-perhutanan-sosial

Terkini News. (2020). IKA SKMA Peduli Covid-19, Berbagi Madu Hutan hingga Paket Sembako ke Masyarakat. Terkini News. https://terkininews.com/2020/05/08/ IKA-SKMA-Peduli-Covid19-Berbagi-Madu-Hutan-Hingga-Paket-Sembako-keMasyarakat

Tropis. (2020). Pedulinya TN Gunung Gede Pangrango berbagi sama penduduk sekitar. Tropis. https://tropis.co/aphi-dan-fkmpi-dorong-upaya-mendongkrak-eksporhasil-hutan-pasca-covid-19 
Victoria, A. O. (2020). Bank Dunia Prediksi 71 juta Orang Menjadi Sangat Miskin Akibat Pandemi. Katadata. https://katadata.co.id/desysetyowati/finansial/5ee1c 17a975dc/bank-dunia-prediksi-71-juta-orang-menjadi-sangat-miskin-akibatpandemi

Vidal, J. (2020). Destroyed habitat creates the perfect conditions for coronavirus to emerge: Covid-19 may be just the beginning of mass pandemics. Scientific American. https://www.scientificamerican.com/article/destroyed-habitatcreates-the-perfect-conditions-for-coronavirus-to-emerge/

WHO. (2021a). Coronavirus disease (COVID-19): Variants of SARS-COV-2. World Health Organization (WHO). https://www.who.int/news-room/questions-andanswers/item/ coronavirus-disease-(covid-19)-variants-of-sars-cov-2

WHO. (2021b). Episode \#45 - Delta Variant. 5 July 2021, Accessed from https://www.who.int/emergencies/diseases/novel-coronavirus-2019/mediaresources/science-in-5/episode-45---delta-

variant?gclid=CjwKCAiAxJSPBhAoEiwAeO_fP88oLvM4zUHBO5ZHvW9CB2zIN SuldulDPdNnX2qxcAuyftfsYJGCLhoChXgQAvD_BwE

WHO. (2021c). Episode \#63 - Omicron Variant. 17 December 2021, Accessed from https://www.who.int/emergencies/diseases/novel-coronavirus-2019/mediaresources/science-in-5/episode-63---omicron-

variant?gclid=CjwKCAiAxJSPBhAoEiwAeO_fP_ZjY63_T7QtzEOLvCoDc_CCgrsb PYJ-OZPualprlkDETellYYwBwxoCIF8QAvD_BwE

Wilcox, B.A \& B. Ellis (2006). Forests and emerging infectious diseases of humans. Unasylva, 57, 11-18.

Wolfe, N. D., Daszak, P., Kilpatrick, A. M., \& Burke, D. S. (2005). Bushmeat hunting, deforestation, and prediction of zoonotic disease. Emerging Infectious Diseases, 11(12), 1822-1827. https://dx.doi.org/10.3201\%2Feid1112.040789

Wright, G. (2011). Indigenous people and customary land ownership under domestic REDD+ frameworks: A case study of Indonesia. Law, Environment and Development Journal, 7(2), 117-130.

Wright, G. D., Andersson, K. P., Gibson, C. C., \& Evans, T. P. (2016). Decentralization can help reduce deforestation when user groups engage with local government. Proceedings of the National Academy of Sciences, 113(52), 14958-14963. https://doi.org/10.1073/pnas.1610650114

Wu, C. I., Wen, H., Lu, J., Su, X. D., Hughes, A. C., Zhai, W., ... \& Zhang, Y. P. (2021). On the origin of SARS-CoV-2-The blind watchmaker argument. Science China Life Sciences, 64(9), 1560-1563. https://doi.org/10.1007/s11427-021-1972

WWF. (2020). The Loss of Nature and The Rise of Pandemics: Protecting Human and Planetary Health. WWF Internasional.

Yuliardi, R. (2020). Apa hubungannya kerusakan hutan, krisis iklim dengan potensi wabah penyakit baru menular?. Greenpeace. https:/www.greenpeace.org/ indonesia/cerita/4901/apa-hubungannya-kerusakan-hutan-krisis-iklimdengan-potensi-wabah-penyakit-baru-menular/ 